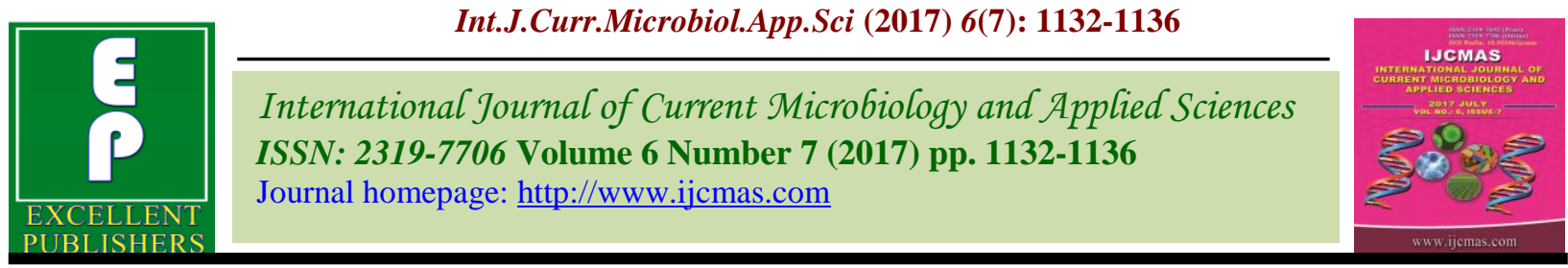

Case Study

https://doi.org/10.20546/ijcmas.2017.607.137

\title{
Effect of Front Line Demonstrations on Yield Enhancement of Fenugreek: A Case Study in Tribal Belt of Rajasthan
}

\author{
Bheroo Singh Bhati ${ }^{1 *}$, R.L. Soni ${ }^{1}$, Rajendra S. Rathore ${ }^{2}$, Ramawtar ${ }^{3}$, \\ Ranjeet Singh ${ }^{1}$ and B.G. Chhipa ${ }^{4}$ \\ ${ }^{1}$ Krishi Vigyan Kendra, Banswara, Rajasthan, India \\ ${ }^{2}$ Rajasthan College of Agriculture, Udaipur, Rajasthan, India \\ ${ }^{3}$ College of Agriculture, Bhilwara, Rajasthan, India \\ ${ }^{4}$ Directorate of Research MPUAT, Udaipur, Rajasthan, India \\ *Corresponding author
}

A B S T R A C T

Fenugreek (Trigonella foenum-graecum L) is a predominantly rabi seed spices crop of Rajasthan. In Rajasthan it is grown in 157 thousand ha area with

Keywords

Technology,

Yield, FLD,

Benefit cost ratio,

Fenugreek.

Article Info

Accepted:

17 June 2017

Available Online:

10 July 2017 production of 190.36 thousand tones with productivity of $1212 \mathrm{Kg}$. /ha. One of the major constraints of its low productivity is non adoption of improved technologies. To demonstrate this 65 Front line demonstrations (FLDs) were organized by KVK, Banswara between 2013-14 and 2016-17 under tribal sub plan of ICAR- NRCSS, Tabiji Ajmer. The Economics and benefit cost ratio of both control and demonstrated plot was worked out. An average of Rs. 54022 gross return was recorded under recommended practices, while it was Rs. 37597 under farmers practice. Benefit cost ratio was 2.25-2.41 under demonstration, while it was 1.61-1.69 under control plots. By conducting FLDs of proven technologies, yield potential and net income from fenugreek production technology can be enhanced to a great extent with increase in the income level of the farming community.

\section{Introduction}

India is well-known as "Land of Spices" across the world since long back. We have been cultivating these precious spices for fulfilling our various needs since ages. Our ancestors have been using these spices for adding taste and flavor in edibles and beverages. It has been used in treatment of various ailments, which is evident from our old literature. These spices possess many medicinal properties. They are carminative, appetizer, digestive, stimulant, tonic, spasmolytic, antipyretic, anthelmintic etc. and these properties increase their importance and value. Spices are valuable due to different aroma, taste and flavour. They change flavour and taste of drink or edible food, whenever added to these products. The aroma of seed spices is due to presence of volatile oil and its quantity determines quality and value. Fenugreek is used in preparing different traditional and ayurvedic medicines. It has many medicinal properties like diuretic, tonic, 
carminative and aphrodisiac. Some special dishes prepared from it are very beneficial in increasing appetite, regulating digestive system and giving relief from joint pain particularly common in old people. In leucorrhoea, 3-6 g of fenugreek powder and 6-12g of sugar candy with 50-100 ml of fresh cow milk should be taken twice daily. Its seeds ground into paste and one teaspoon of the same in lukewarm water taken internally at early morning is helpful in vata diseases, especially in joint pain, back pain etc. Fenugreek is traditionally used to stimulate the metabolism and to help control blood sugar level in case of diabetes.

India is the largest producer of fenugreek seed and it is cultivated on 2.19 lacs hectares land with a production of 247.14 thousand tones in year 2015-16. The fenugreek seed was exported to the tune of 31100 tonnes valued worth Rs. 10835.74 lacs during the year 201213. The Main markets for fenugreek are Japan, USA, UK, Canada, Singapore, Saudi Arabia and U.A.E. In India, its production is concentrated mainly in the state of Rajasthan, Madhya Pradesh, Maharashtra, Haryana, Punjab, Gujarat and Uttar Pradesh. Fenugreek is one of the most important rabi seed spices crop in the Rajasthan state. It occupies about 157000 ha area and 190360 tones production in the state, which is 15.47 per cent and 18.02 per cent of total seeds spices area and production is the highest in the country.

Rajathan and Gujarat contribute more than 80 per cent of the total seed spices production in the country. This belt can, therefore be called as "seed spices bowl" of the country. But the average productivity of fenugreek crop (1200 $\mathrm{kg} / \mathrm{ha}$ ) in the state is very low as compared to other parts of the country. The reasons for low productivity may be the traditional methods of cultivation followed by the farmers. Productivity of the crop can be enhanced by adopting the improved practices as recommended by the Agricultural Universities, Department of Agriculture and ICAR Research Institutes. This study was therefore designed with the objective of assessing the knowledge and adoption of improved practices by the farmers of the tribal belt. The present study was carried out with following specific objectives.

The main objective of FLDs is to demonstrate newly released crop production and protection technologies and its management practices in the farmers' field under different agroclimatic regions farming situations. While demonstrating the technologies in the farmers field, the scientist are required to study the factor contributing higher crop production, field constraints of production and thereby generate production data and feedback information. FLDs are conducted under the close supervision of scientists of National Agricultural Research System comprising of ICAR Institute, National Research Centers, Project Directorates, Krishi Vigyan Kendras and State Agricultural Universities and its regional research stations Choudhary(1999).

FLDs are organized in a block of 2 to 5 hectares involving all those farmers whose plots fall in the identified demonstration block. Only critical inputs and training are provided from the scheme budget, remaining inputs are supplied by the farmers themselves. The purpose is to be convince extension functionaries and farmers together about the potentialities of the technologies for further wide scale diffusion and Front Line Demonstration are used as a source of generating data on factors contributing higher crop yield and constraints of production under various farming situation. The present study was carried out with following specific objective effect of front line demonstration on yield enhancement of fenugreek cultivation in tribal belt of Rajasthan. 


\section{Materials and Methods}

Krishi Vigyan Kendra, Banswara conducted 65 Front Line demonstrations under real farming situations between 2013-14 and 2016-17 at five different villages namely Amarthoon, Gulabpura, Kuwania, Bhompada and Sitatalai in Ghatol block under KVK, Banswara operational area.

The area under each demonstration was 0.20 hectare. Through survey, farmers meeting and field diagnostic visit during the cropping period, low yield of fenugreek was conceived due to imbalanced use of nitrogenous fertilizer and indiscriminate practices to manage aphids (Moyala) and powdery mildew disease.

To manage assessed problem, improved and recommended technologies were followed as intervention during the course of FLDs Programme.

In case of recommended practices, balanced use of fertilizers (N: P: K::25: 20: 20kg/ha) and use of suitable fungicides (Karathane) and pesticide (Dimethoate 30EC) was sprayed. In case of local check (control plots), existing practice being used by farmers i.e. imbalanced use of $\mathrm{N}$ : $\mathrm{P}: \mathrm{K}$ fertilizers, particularly lower doses (10-15 kg N/ha) of nitrogen and use of fungicide/pesticide supplied by local vendors was considered. Well before the conduct of demonstrations, training to the farmers of respective villages was imparted with respect to envisaged technological interventions.

Visits of the farmers and the extension functionaries were organized at demonstration plots to disseminate the message at large. Yield data was collected from control (Farmer's practices) and demonstration plots and cost of cultivation, net income and benefit cost ratio was computer and analysed.

\section{Results and Discussion}

The yield performance and economic indicators are presented in table 1 . The data reveal that the under demonstration plot, the performance of fenugreek yield was found to be substantially higher than that under local check during all the years (2013-14 to 201617). The yield of fenugreek under demonstration recorded was $18.60,20.87$, 21.62 and 21.04 q/ha during 2013-14, 2014$15,2015-16$ and 2016-17, respectively.

The yield enhancement due to technological intervention was to the tune of $34.19,47.39$, 45.49 and 46.72 per cent over control. The cumulative effect of technological intervention over four years, revealed an average yield of $20.53 \mathrm{q} / \mathrm{ha}, 43.45$ per cent higher over local check.

The year to year fluctuations in yield and cost of cultivation can be explained on the basis of variations in prevailing social, economical and prevailing microclimatic condition of that particular villager.

Depending on identification and use of farming situation, specific interventions may have greater implications in different crops in Front Line Demonstration has amply been documented by Chand (2005), Tiwari and Saxena (2003) and Tiwari et al., (2003).

Economic indicators i.e. gross expenditure, gross returns, net returns and $\mathrm{BC}$ ratio of FLDs are presented in table 2.

The data clearly revealed that, the net returns from the recommended practices were substantially higher than control plot, i.e. farmers practice during all the years of demonstration. An average net return from recommended practice was observed to be Rs.30347 in comparison to control plot i.e. Rs. 14822 . 
Table.1 Yield performance of front line demonstrations of fenugreek cv.A Fg-1

\begin{tabular}{|c|c|c|c|c|c|c|}
\hline Year & \multirow{2}{*}{$\begin{array}{c}\text { No. } \\
\text { of }\end{array}$} & \multicolumn{3}{|c|}{$\begin{array}{c}\text { Demonstrations(RP) } \\
\text { Yield (q/ha) }\end{array}$} & $\begin{array}{c}\text { Local check } \\
\text { (FP) } \\
\text { Yield (q/ha) }\end{array}$ & $\begin{array}{c}\text { \% Increase } \\
\text { over FP }\end{array}$ \\
\cline { 3 - 5 } & FLDs & Highest & Lowest & Average & 13.86 & 34.19 \\
\hline $2013-14$ & 12 & 22.40 & 14.30 & 18.60 & 14.16 & 47.39 \\
\hline $2014-15$ & 17 & 24.40 & 17.20 & 20.87 & 14.86 & 45.49 \\
\hline $2015-16$ & 16 & 26.60 & 17.60 & 21.62 & 14.34 & 46.72 \\
\hline $2016-17$ & 20 & 27.30 & 16.50 & 21.04 & \\
\hline
\end{tabular}

Table.2 Economic indicators of front line demonstrations of fenugreek cv.A Fg-1

\begin{tabular}{|l|c|c|c|c|c|c|c|c|}
\hline Year & $\begin{array}{c}\text { Gross Expenditure } \\
\text { (Rs/ha.) }\end{array}$ & \multicolumn{2}{c|}{$\begin{array}{c}\text { Gross Return } \\
\text { (Rs/ha.) }\end{array}$} & \multicolumn{2}{c|}{$\begin{array}{c}\text { Net Return } \\
\text { (Rs/ha.) }\end{array}$} & \multicolumn{2}{c|}{ B : C Ratio } \\
\cline { 2 - 8 } & RP & FP & RP & FP & RP & FP & RP & FP \\
\hline $2013-14$ & 21700 & 20900 & 46500 & 34650 & 24800 & 13750 & 2.14 & 1.65 \\
\hline $2014-15$ & 22900 & 22200 & 55306 & 37524 & 32406 & 15324 & 2.41 & 1.69 \\
\hline $2015-16$ & 24900 & 23900 & 56212 & 38636 & 31312 & 14736 & 2.25 & 1.61 \\
\hline $2016-17$ & 25200 & 24100 & 58070 & 39578 & 32870 & 15478 & 2.30 & 1.64 \\
\hline
\end{tabular}

RP-Recommended Practice FP-Farmers Practice

On an average Rs.15525 as additional income is attributed to the technological interventions provided in demonstrations plots, i.e. balanced nutrition and timely, management of disease and aphids.

The benefit cost ratio of demonstrated plots was observed significantly higher than control plots. The Benefit cost ratio of demonstrated and control plots were 2.14 and 1.65, 2.41 and $1.69,2.25$ and $1.61,2.30$ and 1.64 during 2013-14, 2014-15, 2015-16 and 2016-17, respectively. Hence, favorable benefit cost ratios proved the economic viability of the intervention made under demonstration and convinced the farmers on the utility of intervention. Similar findings were reported by Sharma (2003) in moth bean, Gurumukhi and Mishra (2003) in sorghum, Mokidue et al., (2011) in urd bean and Tomar (2010) in chickpea. The data clearly revealed that the maximum increase in yield and maximum benefit cost ratio of 2.41 was observed during 2014-15. The variation in benefit cost ratio during different years may be on account of yield performance and input output cost in that particular year.
The results of FLDs convincingly brought out that the yield of fenugreek could be increased by 34.19 per cent to 47.39 per cent with the intervention on balanced nutrition coupled with the disease and pest management in tribal dominated Banswara district. Favorable benefit cost ratio is self-explanatory of economic viability of the demonstration and convinced the farmers for adoption of intervention imparted. The technology is suitable for enhancing the productivity of fenugreek crop and calls for conduct of such demonstrations under the transfer of technology programme by KVKs or other Transfer of Technology centers.

\section{References}

Chand, K.2005. Economic analysis of FLD of seed spices in rainfed condition of Rajasthan. CAZRI, Anusandhan Patrika: 45-47.

Choudhary, B.N. 1999. Krishi Vigyan Kendra-A guide for KVK managers. Publication, Division of Agricultural Extension, ICAR: 73-78.

Gurumukhi, D.R. and Mishra, S. 2003. 
Sorghun Front Line Demonstrations-A success story. Agricultural Extension Review, 15(1):22-23.

Mokidue I, Mohanty A.K. and Sanjay K. 2011. Correlating growth, yield and adoption of urdbean technologies. Indian Journal of Extension Education 11(2):20-24

Sharma, O.P. 2003. Moth bean yield improvement through Front Line Demonstrations. Agricultural Extension Review. 15(5): 11-13.

Tiwari, B.K. and Saxena,A. 2003. Economic Analysis of oil seeds in Chindwara.
Bhartiya Krishi Anusandhan Patrika. 16(3\&4):185-189.

Tiwari, R.B., Singh, V. and Parihar, P.2003. Role of Front Line Demonstration in transfer of gram production technology. Maharashtra Journal of Extension Education 22(1):19.

Tomar R K S. 2010. Maximization of productivity for chickpea (Cicer arietinum Linn.) through improved technologies in farmer's fields. Indian Journal of National Products and Resources 1(4):515-517.

\section{How to cite this article:}

Bheroo Singh Bhati, R.L. Soni, Rajendra S. Rathore, Ramawtar, Ranjeet Singh and Chhipa, B.G. 2017. Effect of Front Line Demonstrations on Yield Enhancement of Fenugreek: A Case Study in Tribal Belt of Rajasthan. Int.J.Curr.Microbiol.App.Sci. 6(7): 1132-1136. doi: https://doi.org/10.20546/ijcmas.2017.607.137 